\title{
A methodology of risk assessment and management for a large industrial area
}

\author{
Shiyuan Peng ${ }^{1, *}$ \\ ${ }^{1}$ Environmental Science and Engineering Department, Chongqing Jiaotong university, 400074 No. 66 Xuefu Road, Chongqing, China
}

\begin{abstract}
When investigating large industrial site with very limited site historical information and monitoring data, there will be many challenges to determine the remediation cost and strategy. Here the author illustrates a methodology of risk assessment management for large industrial area. Based on proper conceptual model and professional judgement, a score card for each single site can be generated, including the risk scores for the source, path and receptors. Eventually the score results of the sites can be presented on the overall map through different colour. It is an efficient and direct way which can help the decision maker to tell the priority of allocating the resource for site investigation. The ranking of the site's score will also show an expected cost level of the sites, which could remind the developer to apply more economical strategy at early planning stage.
\end{abstract}

\section{Introduction}

\subsection{Background}

The area under investigation is about 4.5 square kilometers and is situated in one of the large cities in China. The area underwent an important expanding phase and development in the 50s' and 60s' of the last century. A report by an international consultancy was made available, compiling the results of 3 sampling campaigns over a period of about 13 months. The investigation team was requested to review the report and provide (1) an estimation of the overall remediation cost and (2) an average remediation cost per $\mathrm{m}^{2}$.

The report contained information in relation to 40 boreholes and 17 groundwater wells. The report provided field observations, bore logs, PID measurements during drilling, water level registrations, field measurements like $\mathrm{pH}$ and electrical conductivity of groundwater samples, etc.

Both soil and groundwater had been screened for heavy metals and organic analytical content (GC-MS). Additional to the investigative data the names of the sites disclosed some of the former activities. Names like Rubber plant, Chemical plant, Battery plant, Coking plant, Dyeing plant disclosed the (former) activities on the various sites.

In order to get to know the sites up close and meet the client, a site visit was organized. Although the site visit did not reveal any additional data, the site provided recognition of the surroundings and the conceptual build-up to the industrial plants in the area. It became also clear that not the full area was under investigation and up for redevelopment. Some sites were large sites already redeveloped, some of the large sites had only been green land in the past. The complete opposite case was a small site that had clearly a $\mathrm{CS}_{2}$-plume in the groundwater.

\subsection{Challenges}

Urban planning and redevelopment of an industrial area this large, brings on specific challenges [1]. The environmental impact of current or past industrial activities will influence the urban planning process, like any other decision-making process is based on data and information to support the decision. Not all information is always available at the beginning. For long-history, shutdown factory, it is very common that key process information is missing. Data will be generated and information researched when necessary. Generating sufficient monitoring data involves allocating resources (time, people and money) in accordance to the priorities as envisioned in a project development plan.

The limited but analytically good site investigation report posed a double challenge. The sampling points were not closed enough to the actual activities and too limited to make any practical assessment. At the same time going through the analytical reports some low concentrations were registered and some regional impact appear in the groundwater analytical results.

What was clearly missing was the footprint of the contamination, with some of the sites being completely demolished and derelict, no clear information was available to provide quantitative information as a measure for comparison of any scale of contamination.

Under this condition, classic risk-modeling alone is considered not suitable. Although the quality of calculations for such as CSOIL [2], or RBCA [3] is high and the scientific basis is extensively elaborated, the basic input data needs to come from thoroughly sampling and measurements to generate data specific for

\footnotetext{
* Corresponding author: judy.peng@cqjtu.edu.cn
} 
the site. Only by this the analytical data will satisfy the need to have a high degree of certainty before a detailed calculation would render results with a high degree of certainty. The limited data set form the previous report does not allow classic risk modeling at this point.

\section{Scorecard methodology}

\subsection{Concept model}

One must take comprehensive consideration when dealing with large industrial area, because the environmental impact of one specific site often can leave the site itself and migrate over the boundaries of a site towards the surrounding area. This calls in the need for two sets of methodologies. A semi-qualitative approach at the beginning of the data collection process, which like the scorecard methodology and later on the riskmodelling method based on a scientific data set. The two methods are interlinked. The following figure illustrate how both methods are integrated at early stage, when the investigators adopt the scorecard methodology.

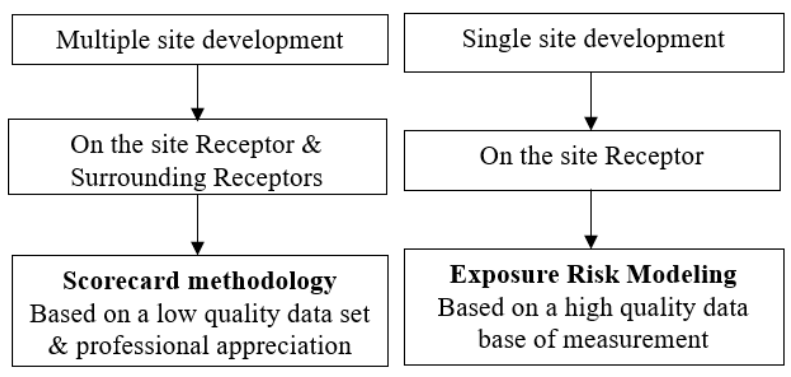

Fig. 1 Comparison between single site development and multiple site development. When Multiples sites are been developed, both "on site receptors" and "surrounding receptors" are relevant.

As illustrated below(Fig.2) how "Site specific risk modeling" will be used to evaluated the risks on a site for a "on site receptor". Interaction of contamination towards the nearby surrounding area cannot be modeled with a risk modeling and therefore there is a need for an additional methodology.

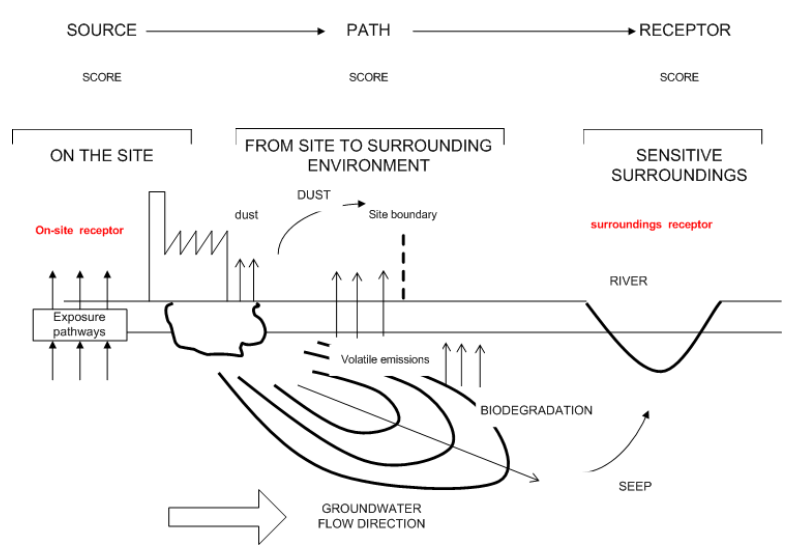

Fig. 2 The concept of "Source-Path-Receptor". Note that sensitive surroundings are added to the concept model.
The solution to processing all the data into a system lies in using the Source-Path-Receptor concept to form a scorecard result. By scoring Source/Path/Receptor criteria on a multi-criteria a matrix can be built, allowing to provide a measure to assess impacts on the sites as also the impact to the direct surrounding environment.

\subsection{Score system}

The source score would have two components or be a composite of two scores. First there would need to be a measure for the scale of the "possible" impact. Second the signature of the contamination in terms of human toxicology and exposure [4] in the current and possible future land use would need to be evaluated. This last measure would be strictly limited to the situation on the site. Here below shows examples of different score.

Tabel 1. Scource score under different scenario

\begin{tabular}{|c|c|c|}
\hline \multirow{4}{*}{ Scale } & scenario & score \\
\cline { 2 - 3 } Health impact & $\begin{array}{c}\text { Small scale plastics factory- } \\
\text { water bottle factory }\end{array}$ & $4 / 5$ \\
\hline & $\begin{array}{c}\text { Chemical factory with various } \\
\text { type carcinogenic chemicals at } \\
\text { high concentrations (also } \\
\text { volatile) }\end{array}$ & $5 / 5$ \\
\cline { 2 - 3 } & $\begin{array}{c}\text { Plastics factory: Phthalates, } \\
\text { often applied for food } \\
\text { packaging }\end{array}$ & $2 / 5$ \\
\hline
\end{tabular}

The path score represent the possible distribution and migration of impacts beyond the site boundary. Possible ways of migration that could travel to adjacent sites or groundwater that flows in the direction of next door sites. The path score is also related to the chemichal features of the potential pollutants, such as solubility, retardation, if it is biodegradable into more toxic daughter products, etc.

The Receptor Score is a translation of the sensitivity of the surrounding area in terms of land use. This means that residence time, type of activity, sensitivity of the subjects of the surrounding sites are taken into account. The table below explains the score for both the 'on-site receptor' and 'the surround receptor' for the sites under suspicion, all supposing that one or more sources of contamination are present on the sites. Because the investigator had no data about receptors at the time and this should be subject of further investigation, the Surrounding receptor score is at this point a translation of "how far and what chances are that a potential receptor is reached", later in the process the scoring can represent more the sensitivity of the receptor as such.

Table 2 Receptor score criteras for "on-site receptor" and "Surroundings receptor score"

\begin{tabular}{|c|c|c|}
\hline Type & Description & Score \\
\hline \multirow{2}{*}{$\begin{array}{c}\text { On-site } \\
\text { recptor }\end{array}$} & $\begin{array}{c}\text { Carcinogenic chemicals or a } \\
\text { combination of suspected Carcinogenic } \\
\text { chemicals }\end{array}$ & 5 \\
\cline { 2 - 3 } & Non-volatile carcinogenic chemicals & 4 \\
\hline
\end{tabular}




\begin{tabular}{|c|c|c|}
\hline & $\begin{array}{l}\text { Non carcinogenic chemicals but } \\
\text { hazardous or neurotoxicological or } \\
\text { direct adverse effect due to exposure } \\
\text { pathway property to chemical e.g. } \\
\text { volatility }\end{array}$ & 3 \\
\hline & $\begin{array}{c}\text { Non hazardous chemicals, non } \\
\text { carcinogenic chemical, with limited } \\
\text { effect, only indirect (dermal) contact } \\
\text { hazardous }\end{array}$ & 2 \\
\hline & Non toxic, food grade chemicals & 1 \\
\hline \multirow{5}{*}{$\begin{array}{l}\text { Surrouding } \\
\text { receptor }\end{array}$} & $\begin{array}{l}\text { Based on Source and Path score it is } \\
\text { highly likely that the sensitive receptor } \\
\text { is reached in the current situation }\end{array}$ & 5 \\
\hline & $\begin{array}{c}\text { Based on Source and Path score it is } \\
\text { likely that receptor is reached }\end{array}$ & 4 \\
\hline & $\begin{array}{l}\text { Based on Source and Path score a } \\
\text { receptor might have been reached but it } \\
\text { is uncertain. } \\
\end{array}$ & 3 \\
\hline & $\begin{array}{c}\begin{array}{c}\text { No sensitive receptor in the area, likely } \\
\text { that no receptor is reached outside the } \\
\text { contaminated site }\end{array} \\
\end{array}$ & 2 \\
\hline & $\begin{array}{l}\text { Except for the on site itself not } \\
\text { receptor in surrounding reached with } \\
\text { additional effect }\end{array}$ & 1 \\
\hline
\end{tabular}

\subsection{Scoring each separate part of the multi criteria matrix}

Here we illustrate the method by taking three different sites as example. Firstly in order to determine the scale of the operations and activities on site, an analysis was made by the sets of aerial pictures available. Together with the observations during the site visits, a core or footprint of the activities could be established. By measuring the surface area of several relevant sections of the operations, an overall activities \& operations footprint was calculated.

For the health impact score, the measured analytical chemical compound in either soil or groundwater were listed independent of their concentration and special (distance) relation to any potential source on the site. The human health score would then be a measure of the carcinogenic characteristics of the chemicals measured and also would take into account compound accumulated exposure if several chemicals are involved. In the table below additional information is stated like Activity on the site \& Guiding parameters, this information is stated to allow appreciation or re-evaluation of the score if more information was gathered over time.

Table 3 Examples of source scoring in the multi criteria matrix

\begin{tabular}{|c|c|c|c|c|c|}
\hline & \multicolumn{2}{|c|}{ Scale } & \multicolumn{3}{|c|}{ Health impact } \\
\hline & $\begin{array}{c}\text { Surface } \\
\left(\mathrm{m}^{2}\right)\end{array}$ & Score & Activity & $\begin{array}{c}\text { Guide } \\
\text { parameters }\end{array}$ & Score \\
\hline 1 & 24156 & $3 / 5$ & $\begin{array}{l}\text { Dyeing, basic } \\
\text { chemistry }\end{array}$ & $\begin{array}{l}\text { Chlorinated, } \\
\text { furans, heavy } \\
\text { metals, anilines }\end{array}$ & $5 / 5$ \\
\hline 2 & 32767 & $3 / 5$ & $\begin{array}{l}\text { Naphthalene } \\
\text { derivates }\end{array}$ & BTEXN & $5 / 5$ \\
\hline 3 & 91207 & $4 / 5$ & unlear & PAH, carbozols & $4 / 5$ \\
\hline
\end{tabular}

The path score takes into account a possible migration of the contamination beyond the site boundary. This mobility can be a result of solubility in groundwater by which the contaminant can travel through groundwater migration. When a considerable amount of contamination migrates the volatile aspect of the contaminant can be relevant to determine if the contamination would travel to the surface of a site next to the source site.

Table 4 Example of path scoring in the multi criteria matrix

\begin{tabular}{|l|l|l|l|l|}
\hline & Volatility & \multicolumn{1}{|c|}{ Solubility } & \multicolumn{1}{|c|}{ Degradable } & Score \\
\hline 1 & yes & soluble & $\begin{array}{l}\text { yes, except for some } \\
\text { metals }\end{array}$ & $4 / 5$ \\
\hline 2 & yes & soluble & yes & $4 / 5$ \\
\hline 3 & limited & $\begin{array}{l}\text { PAH no, TPH } \\
\text { yes, phthalates } \\
\text { yes }\end{array}$ & limited & $2 / 5$ \\
\hline
\end{tabular}

The receptor score translates the sensitivity of the surrounding area. If there is no direct use or only industrial use in the direct vicinity of the site, then the score would be low. If a clearly well ecologically developed waterway is adjacent or a school is next to the site, then the receptor score is high.

The table below illustrates the score card results. Sites with a higher score are sites that are under suspicion of have higher impacts with more impact to the surrounding environment.

Table 5 The score card results

\begin{tabular}{|l|l|l|l|l|l|}
\hline & \multicolumn{2}{|c|}{ Source score } & \multirow{2}{*}{$\begin{array}{c}\text { Path } \\
\text { score }\end{array}$} & $\begin{array}{c}\text { Receptor } \\
\text { score }\end{array}$ & $\begin{array}{c}\text { Total } \\
\text { score }\end{array}$ \\
\hline & scale & health impact & $4 / 5$ & $4 / 5$ & $16 / 20$ \\
\hline 1 & $3 / 5$ & $5 / 5$ & $4 / 5$ & $4 / 5$ & $16 / 20$ \\
\hline 2 & $3 / 5$ & $5 / 5$ & $2 / 5$ & $1 / 5$ & $11 / 20$ \\
\hline 3 & $4 / 5$ & $4 / 5$ & \multicolumn{2}{|c}{} \\
\hline
\end{tabular}

\subsection{The score card presentation with coloured map}

In line with the total score of each sties, a legend coloration was established to provide fast interpretation on a map (Fig. 3). But not only a color is given, also the individual scores and the overall score is given in an informational window. This again facilitates the review of maps by checking the score and allowing the map to become a life document, that can change over time. The use of both the score matrix and the map allows consultation relevant data prior to consulting the investigative detailed information. 


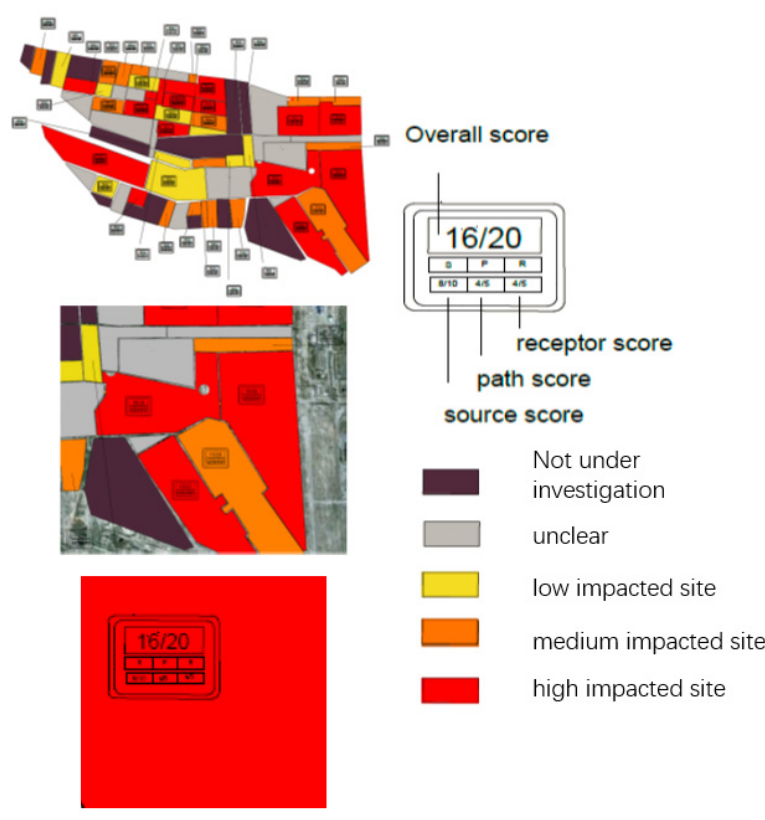

Fig. 3 Overall colouring on the industrial area map. The overall coloration gives a ranking or priority of the site and its environmental presumed possible impact, including the

possible impact to the surrounding environment. The scores in the table above are illustrated on a map in a colour grading from 'yellow' to 'red', with 'red 'being the more suspicious sites.

\section{Discussion and conclusion}

The market for soil remediation in China is booming in recent years $[5,6]$. Yet for large scale contaminated site, the initial data could be very limited at the beginning or even before an official redevelopment planning, which makes it almost impossible to provide an assessment of initial remediation strategy and costs for an industrial area of $4.5 \mathrm{~km}^{2}$.

By looking at all the data in the investigative report, site visit and acquiring additional information from aerial pictures, a large data set was obtained. The full integration of this dataset in the concept of the "SourcePath-Receptor" linkages by providing a score, has allowed to provide a ranking of the sites. The Scorecard methodology is developed to help prioritize the allocation of resources for site investigation, with five level for each components, which generates priorities in a ranking of "suspicious" sites with the need be investigated first.The ranking can be plotted on a map to visual represent the sites more under suspicion of contamination than others. Additionally, the impact towards the surroundings are taken into account. These priorities can be changed and adapted based on the combination urban planning priorities and environmental priorities.

Indirectly the score would represent a presumed remediation cost ranking, whereby the surface area of the footprint analysis can be a measure for the impacted subsurface.

The methodology presented in this article actually provides a tool which can be used by urban planners when redeveloping larger industrial areas. It can be a ranking for site investigation priority or can be a reference for the follow-up of the site investigation results themselves. Additional more add-on information can be integrated to provide for more precise scores and information which can be applied to measure and represent the actual status of an on-going redevelopment process.

As scale of the industrial activities is a criterion in both the priority score and the expected remediation cost, the effort in searching for smart remediation solutions should be targeted at the large sites with a higher score on the priorities map. Smart solutions will not only be focused on source elimination, but also on the combination of smart urban planning and smart engineering of sites by e.g. landscaping in order to cut "receptor pathways" for receptors on a site or cut "source-path-receptor" linkages towards receptors in the nearby surrounding area of a contaminated site[7].

However, the more insufficient data from the initial report, the more professional experience will be required for the score maker. The accuracy of the scores depends much on the investigator's own experience. A lot of additional research should be done to substantiate or adjust the scoring on the various criteria at this point, and finally determine the exact soil remediation cost.

\section{Acknowledgement}

This work was supported by the Science and Technology Research Project of Chongqing Education Commission (KJQN201800742).

Disclaimer: The aerial pictures and maps used throughout this article are aerial pictures of an industrial area somewhere in Asia. Throughout this article we will use pictures of the same location to illustrate the approach which was developed. The pictures used are not from the actual site, but will serve to set out the methodology used and illustrate the results obtained. By using these pictures there is no implication meant whatsoever as to the activities, land use and quality of the land and subsurface soils and groundwater. The aerial pictures were available by Google Earth.

\section{References}

1. K. Cao, H. Guan, Chin. Geogr. Sci.17(2),127-134, (2007)

2. E. Brand, P.F. Otte, J.P.A. Lijzen, CSOIL 2000: an exposure model for human risk assessment of soil contamination - A model description RIVM report71170154, (2007)

3. Standard Guide for Risk-Based Corrective Action Applied at Petroleum Release Sites ASTM E.173995, (2010)

4. K. Gruiz, T. Meggyes, E. Fenyvesi (Eds.) Engineering Tools for Environmental Risk Management: 2. Environmental Toxicology. CRC Press. ISBN 9781138001558 (2015) 
5. D. Hou, G. Li, P. Nathanail, Front. Environ. Sci. Eng. 12(1), 16 (2009)

6. S. D. Chiang, Q. Gu, Rem. J. 25(3), 85-99 (2015)

7. F. Zhao, Y. Ma, Y. Zhu, Z. Tang, S. P. McGrath, Environ. Sci. Technol.49(2), 750-759(2015) 